\title{
Characteristics and perception of social support by patients with fibromyalgia in Facebook
}

\author{
Características e percepção de apoio social por pacientes com fibromialgia no Facebook
}

Felipe Azevedo Moretti ${ }^{1}$, Sandra Santos Silva², Claudia Galindo Novoa ${ }^{1}$

DOI 10.5935/2595-0118.20180003

\section{ABSTRACT}

BACKGROUND AND OBJECTIVES: Analyze the interactive behavior, characteristics, perception of social support, and interests of patients with fibromyalgia on online discussion groups. METHODS: A participatory netnography has been conducted for 6 months on Facebook in order to keep track of a fibromyalgia community with more than 8,000 members. An electronic survey composed by a validated social support scale was sent to the members of the group. Another online survey was applied by the group coordinator in order to build the users' profile.

RESULTS: The online environment has often been indicated as the only place to get something off one's chest. Regular testimonials on social discrimination due to Fibromyalgia were recorded, coming from the family itself, from friends and even from health professionals. Patients' rights and new treatments are among the topics of greatest interest. The target group seemed to have a social echo, but it has difficulties to generate engagement among its members. Low social support was reported by most of the 444 respondents. However, many also criticized the group positively. There were 3,217 people who responded the survey applied by the coordinator: $97.5 \%$ female respondents, $86.2 \%$ were between 31 and 60 years old, $60.1 \%$ were diagnosed by a rheumatologist, $16.5 \%$ by an orthopedist, and $6.8 \%$ by a general practitioner. The five most unpleasant symptoms informed were: pain, anxiety, memory problem, irritability, and tingling.

CONCLUSION: New forms of online education and social support for fibromyalgia on online groups are relevant resources to be considered in patient care programs.

Keywords: Fibromyalgia, Social networks, Social support.

1. Universidade Federal de São Paulo, Programa de Pós-Graduação em Gestão e Informática em Saúde, São Paulo, SP, Brasil.

2. Associaçăo Brasileira dos Fibromiálgicos, Itanhaém, SP, Brasil.

Submitted in October 03, 2017.

Accepted for publication in January 04, 2018

Conflict of interests: none - Sponsoring sources: Programa Telessaúde Brasil Redes.

Correspondence to:

Rua Botucatu, 740 - 3०A - Sala 307 - Vila Clementino

04023-062 São Paulo, SP, Brasil.

E-mail: felipe.moretti@unifesp.br

(C) Sociedade Brasileira para o Estudo da Dor

\section{RESUMO}

JUSTIFICATIVA E OBJETIVOS: Analisar o comportamento interativo, as características, a percepção de apoio social e os interesses de pacientes com fibromialgia em grupos de discussão online.

MÉTODOS: Foi feita uma netnografia participativa que acompanhou por 6 meses uma comunidade de Fibromialgia com mais de 8.000 membros no Facebook. Um inquérito eletrônico sobre suporte social com escala validada foi enviado aos membros do grupo. Outro questionário online para traçar o perfil dos usuários foi aplicado pela coordenadora do grupo.

RESULTADOS: O ambiente online foi apontado frequentemente como único local de desabafo. Registraram-se depoimentos regulares sobre discriminação social decorrentes da Fibromialgia - advindos da própria família, de amigos e, até mesmo, de profissionais de saúde. Direitos dos pacientes e novos tratamentos aparecem dentre os temas de maior interesse. O grupo acompanhado mostrou ter repercussão social, mas apresenta dificuldades para gerar envolvimento entre os membros. Baixo apoio social foi alegado pela maioria dos 444 respondentes. No entanto, muitos também criticaram positivamente o grupo. $\mathrm{O}$ questionário aplicado pela coordenadora teve 3.217 respondentes, a saber: $97,5 \%$ do sexo feminino; $86,2 \%$ com idade entre 31 e 60 anos; $60,1 \%$ cujo diagnóstico foi dado por um reumatologista, $16,5 \%$ por ortopedista e $6,8 \%$ por clínico geral. Os cinco principais sintomas mais desagradáveis citados pelos pacientes foram: dor, ansiedade, problema de memória, irritabilidade e formigamento. CONCLUSÃO: Novas formas de educação online e de apoio social em grupos virtuais para fibromialgia são recursos relevantes a serem considerados em programas de atenção a pacientes.

Descritores: Apoio social, Fibromialgia, Redes sociais.

\section{INTRODUCTION}

A systematic review by Cochrane ${ }^{1}$ showed that the mere identification of similar cases or symptoms among individuals with similar problems on online networks can be an excellent instrument to handle chronic conditions, among them the fibromyalgia (FM), offering improvement for the health of the users, promoting bigger autonomy and proactivity, as well as benefits that improve social interaction, reduce hopelessness, provide more knowledge about the disease, expand behavior strategies and better clinical outcomes of diseases such as rheumatoid arthritis (RA), cancer and $\mathrm{FM}^{1,2}$. However, the authors suggest more 
studies as a way to consolidate the best practices and to compare the results from different strategies.

Making use of educational initiatives in the treatment of FM has proved to be a valuable resource to control pain, fatigue, and depression with benefits that usually remain in the long run, showing superiority to the conventional treatment alone and with evidence of cost-effectiveness in economic analysis ${ }^{3,4}$.

These benefits have already proved to be viable, useful and promising in the online universe of FM support and education groups 5 . However, there is still a shortage of studies to evaluate the results of different models and identify the difficulties, the potential and possible promising actions to be offered by the existing groups or groups that will be created, even as a guiding mechanism to improve the service provided.

According to van Uden-Kraan et al. ${ }^{6}$, a researcher from the University of Twente (The Netherlands) who studies the subject of virtual support groups to chronic problems, it is possible to find important weaknesses in terms of quality and validity of the information that sometimes travel online. In addition, these environments can also provide an inadequate opinion in the social or behavior point of view. Yet, Johnsen, Rosenvinge, and Gammon $^{7}$ state that in specific communities for online support in the field of mental health, there are, sometimes, negative comments that are strengthened by other participants, thus creating a destructive line of negativity. However, despite the weaknesses, van Uden-Kraan et al. ${ }^{8}$ indicate that, when put on the scale, the positive effects tend to overcome the possible negative contributions. Frost and Massagli ${ }^{9}$ point out that talking in online environments of dialogue and questioning the behaviors of other members that suffer from the same disease, with the possibility of exchanging personal experiences, locate other people and offer knowledge on health management tend to solidify relationships. But few studies have examined the details in using these mechanisms.

In this sense, understanding the patterns of interactive behavior, the themes of interest and the profile of patients with chronic pain (in this case, fibromyalgia) who attend online discussion groups, as well as to identify ways to enhance such groups are important research steps.

The objective of this study was to analyze the interactive behavior, characteristics, the perception of social support and the interests of patients with FM in online discussion groups.

\section{METHODS}

An exploratory survey was initially conducted to identify relevant discussion groups on Facebook addressing the subject of FM. More than 100 communities of virtual support for FM in Portuguese were found. The community selected for the netnography has a high number of members $(8,197$ on 10/14/2015) and a nationwide patients' association connected to the group and to a complementary information channel that has already been awarded by the public with the Top Blog Award in the health category.

Other reasons that guided the selection were the fact that the community is closed and has many active individuals, clear participation rules, and 14 administrators in the occasion (what was considered to provide high capillarity, decentralization and a greater likelihood of social impact). Moreover, one of the mottos of the group was the creation of strong bonds among members one of the study objectives of the research.

It is worth mentioning that netnography has proven to be a useful method in research aiming at new findings related to digital communication ${ }^{10}$, even in the health area ${ }^{11}$.

After the selection of the community, we requested a formal authorization from the coordination to follow the group, who supported the study and notified users of the research.

The phase of participative netnography began with electronic annotations of posts with many shares or likes, field records on topics of greatest interest and listing of interactive behaviors stored in a temporary record by the software OneNote. In addition, over six months, the main researcher interacted with the members of the virtual community, conducting interviews and distributing an electronic survey on social support. The survey consisted of a social support validity scale, the Social Support Satisfaction Scale (SSSS), in addition to supplementary questions related to the subject of the study, such as amount of meaningful friendships made in the group, suggestions for improvement for future groups, positive and negative criticism regarding the network, suggestions for new activities, degree of involvement with the group, among others.

All the 444 respondents who had completed the social support electronic survey signed the free and informed consent before answering the research. Only five subjects refused to sign the electronic consent, being excluded from the statistical analysis.

To reach the described sample, the main researcher sent inbox messages on Facebook to most of the group members, informing about the research and inviting them to collaborate with the study. The sample of 444 respondents was established as representative of the studied universe. As a calculation basis, it was used the estimate of 8,000 patients in the network as the study universe because it was identified that approximately $5 \%$ of the participants of the online group were health professionals, family members, friends or people interested in the subject. To establish the sample calculation with a confidence level of $95 \%$ and $5 \%$ of error margin, the sample size required was 367 respondents.

It is important to highlight that before the application of the social support electronic survey; the group coordinator initiated an opinion poll with the participants of online communities on Facebook connected to the institution that she runs in order to characterize the patients with FM that participate in these discussion settings. Then, in order to complement the present article, the author of the survey was invited to present part of her data. The group coordinator used the Google Form tool for the survey and shared the results with the main researcher of the present article. The questionnaire consisted of questions about age, gender, medical specialty who provided the FM diagnosis, most unpleasant symptoms, place of residence, monthly income, treatments, the amount spent with treatments, among others.

Despite her participation in co-authorship of the manuscript, since some of the descriptive data were collected by her, the survey coordinator had no interference in the article writing, nor in the form the data is presented, since this could represent a con- 
flict of interest in the form of presentation of the netnography results and of the social support survey.

This study was approved by the Committee of Ethics of the institution under record number in Plataforma Brasil: CAEE 47925615.8.0000.5505.

\section{RESULTS}

By the netnography, it was possible to observe that many participants pointed out the online environment as the only place to vent their feelings with intimate, deep, suffered reports and broad exposure of personal data.

With such stories, we observed empathy behaviors from the group and active contribution from the moderators with affectionate and constructive comments. Similarly, it was also observed slightly disconnected contributions, for instance likes for extremely sad/hard situations, as well as abrupt changes of topics discussed. Regular statements were recorded about social discrimination due to the disease - coming from family, friends and health professionals who often question the veracity of the symptoms, alleging to be a purely psychological syndrome, and also showing discredit and ignorance. The discrimination posts generally get a lot of likes, shares, and comments reinforcing that this is absolutely commonplace. The group has characteristics very similar to mutual help associations, where there is collaboration among peers with the exchange of experiences, recognition, and appreciation of the difficulties of others. There are also congratulation posts on birthdays, for overcoming challenges, in addition to the intense and relevant participation of the moderators.

The coordinator told that the moderators are regularly trained due to the high turnover of volunteers in this function.

Improper Posts receive a warning message when they do not follow the rules, and members can be excluded or blocked. The veto and the exclusion of some freer manifestations of the collective sometimes imply in dissatisfaction and disengagement of certain people of the community.

There are also reading suggestions, news highlights and criticism to articles deemed of low credibility when they are posted to the group.

Regular comments on difficulties to get people to help in the group moderation, as well as frequent requests for more engagement of the users.

To evaluate possible topics to be debated, the members receive surveys to state their interest, questionnaires to evaluate the participants' degree of knowledge about the syndrome, and questions so that they can express their personal feelings about the participation in a collective digital environment.

Patients' rights and new treatments are among the topics of greatest interest expressed by the participants.

In the survey answered by 444 individuals, $72.1 \%$ (320) of the participants said they did not make any significant friends in the group, followed by $7.9 \%$ (35) who made just one friend, $6.1 \%$ (27) who made two friends and $4.7 \%$ (21) who made three friends. The remaining percentage of those who said they have made more than four friends was always below $2.9 \%$ for the other categories that ranged from four to 10 (or more) friends made.
However, although few significant friendships were made, the majority of the respondents $(>60 \%)$ miss somebody truly close to vent their feelings, and approximately $70 \%$ miss social activities a lot.

When it comes to the question of how engaged the users were with the activities of the group, most of the participants reported a low involvement, and only $22.8 \%$ had an involvement above the average of 5 (in a scale where 10 was the maximum involvement), $19.4 \%$ (86) reported an average involvement (that is, score 5) and the remaining of respondents (57.9\%) reported a low or very low involvement with the activities.

However, despite this low involvement with the group's activities, in reply to an open question - where participants were invited to speak freely about the virtual group they participate, the positive comments were more frequent than the negative, with frequent reports expressing the importance of the group for the day-to-day, compliments to the great efforts, encouraging speeches and a lot of gratitude.

As for the most frequent suggestions about what could be improved in these virtual FM groups, virtual conferences appeared in first among the given answers. Ways to help and provide interaction among users were also some of the main topics, as well as the support of more healthcare professionals, the need of psychological and legal support, and also the creation of regional discussion forums. Other frequent suggestions were: dissemination of trustworthy research, a listing of medical experts, physical attendance meetings and more technical videos on the subject.

The state of health the patients attributed themselves is usually from regular to very bad. Of the 444 respondents, $51.1 \%$ (227) considered their health bad or very bad. Yet, $37.8 \%$ (168) considered their health state reasonable; $10.6 \%$ (47) reported a good health state and $0.5 \%$ (2) said they were in very good health.

Other complementary data from the 444 respondents are that $73.9 \%$ (328) are married or in a steady relationship, and $71.6 \%$ (318) have children. Other characterization data of the 444 respondents (such as gender, age, education level, and income) are very similar to the results collected in the questionnaire applied by the coordinator, described below.

The questionnaire applied by the coordinator of FM virtual groups had 3,217 respondents. It was instructed that only individuals that have already received a previous diagnosis of FM from a physician should answer the online questionnaire. However, it is important to highlight that when refining the answers database, some duplicates and errors were found in approximately $3 \%$ of the fields. Therefore, it is suggested to consider such margin of error in the interpretation of the data of this article.

Of the total of 3,217 respondents, $97.5 \%$ were female and $86.2 \%$ with age between 31 and 60 years. Of the total of respondents, $60.1 \%$ received the diagnosis from a rheumatologist, $16.5 \%$ from an orthopedist and $6.8 \%$ from a general practioner. The five major unpleasant symptoms reported were pain, anxiety, memory problem, irritability, and tingling.

As for the education level of the sample, 26.7\% (859) have completed high school, 22\% (707) had superior education, $19.8 \%$ (637) had a post-graduation, and $15.5 \%$ (499) had an incomplete superior education. These were the first 4 categories with the highest number of respondents. 
Of the total sample, $44.7 \%(1,437)$ were from the Southeast of Brazil, 19.8\% (636) from the South, 18\% (578) from the Northeast, $10.8 \%$ (357) from the Midwest, $4.2 \%$ (134) from the North, and the others from other regions/countries.

The personal monthly income that predominated was between $\mathrm{R} \$ 1.001,00$ and 3.000,00 - with 31.4\% (1,010) respondents self-reporting such income. Followed by $21.2 \%$ (682) who did not have any remuneration (being financially dependent on someone else). Then, $20.2 \%$ (650) reported a monthly income up to R \$ 1.000,00; 13\% (419) between R \$ 3.001,00 and 5.000,00; and 4.6\% (149) between $\mathrm{R} \$ 5.001,00$ and 7.000,00. The others fell into other categories.

\section{DISCUSSION}

Web-based education strategies for rheumatic patients have already shown to be promising for diseases as RA and $\mathrm{FM}^{1,5}$. A renowned education program for self-management for rheumatology ${ }^{12}$, replicated in several countries with the support of the American College of Rheumatology, was structured online and showed to be superior to the conventional treatment in a randomized study with 855 patients with FM, RA, and osteoarthrosis ${ }^{13}$.

It is important to say that the online education format proposed by Lorig et al. ${ }^{13}$ was exactly an attempt to give support to a broad universe of patients who enter the virtual environment searching for health information. In these virtual searches, such patients end up in discussion groups on Facebook and other interactive platforms. In an online search on Facebook in August 2017, we found 98 FM groups, 102 pages on FM and other dozen groups that appeared in the personal profile category when running the search with only the "Fibromyalgia" keyword in Portuguese.

As a suggestion for a higher possibility of success of these communities, van Uden-Kraan et $a .^{6}$ point out that the moderators of these online groups should dedicate 10 to 15 hours weekly due to the wide demand required by the users of these communities.

Camerini, Camerini and Schultz 5 also mention the importance to provide personalized content with individualized attention as a way to increase the global efficacy of these groups.

In spite of these considerations in the present study and the active and intense contribution from the moderators, it was observed the difficulty in sending individualized messages to the users, due to reasons usually associated with the high number of members, because it is an action that requires a lot of work to be performed without automation, it is a voluntary work (which dedication tends to be compromised by the fragile functional bond) and due to lack of financial resource to provide better structured activities. Such difficulties have already been observed in other research on rheumatic patient associations ${ }^{14}$ and must be taken into account when opening new groups.

As part of the research, when interviewing an active patient of these FM groups and questioning her about the most relevant initiatives she has participated, it catches the attention that the majority she listed has thousands of users. Below is the list sent by the patient in June 2017 with the respective number of users listed by the patient. "Fibromyalgia I have friends" (17,600 mem- bers); "I have fibromyalgia (13,600 members); "Commission of Fibromyalgia patients - Pro National Association" (11,600); "I have Fibromyalgia, what now?" (10,500); "Knowing more about fibromyalgia (10,300); "Fibromyalgia Association" (9,000); "Fibromyalgia - sharing experiences" $(8,800)$; "Friends with Fibromyalgia" (4,300); "Positivism in Fibromyalgia (880).

As a counterpoint, it is worth pointing out that the format of the self-management education programs for rheumatology mentioned in the first paragraph of this discussion, give as a methodological model the creation of small groups of patients (up to 25 members).

As for the findings on low social support reported by the 444 individuals in the electronic survey and the small number of users with FM that made friendship bonds online, some possible hypothesis was proposed for this apparent fragility in building stronger social bonds, such as isolation due to the disease itself ${ }^{15}$ (since more than $50 \%$ of the respondents said their health was very bad and bad, which makes social interaction more difficult), the presence of a certain invisibility in a ocean of so many members ${ }^{16}$, and a postmodern culture of liquidity - which stimulates weak social bonds $s^{17,18}$, and the current monetary and social logic that values more the quantity at the expense of intimacy or depth of human relations. However, the construction of closer interpersonal relations is a process that is highly desired by the members, and more than $60 \%$ of the participants miss somebody truly close to vent their feelings, and approximately $70 \%$ miss social activities a lot. In addition, ways to help and provide interaction among users were also topics suggested as improvements to these FM groups.

With regard to this analysis, the studied group showed to have social repercussion and impact in the life of its members. However, it faces difficulties to motivate the users to have more active participation and interpersonal involvement. However, to build strategies that drive the social support within these communities is something that deserves attention, because it is exactly in the networks with strong bonds that there is a common identity, and it is where people search for references in their decisionmaking process. According to Granovetter (apud Kaufman) ${ }^{17}$, it is with strong bonds that comes the feelings of trust among the members of a community. Granovetter says that the stronger the bonds in their networks, more consistent are the decisions they make. According to Kaufman:

"The new digital informative architecture provided an exponential growth of 'Weak Bonds' networks, with the formation of the so-called 'Virtual Communities', around 1985, that expanded after 1994 with the advent of the web and boosted after 2004 with the social networks. By looking at the profile of the members of the key communities, we found participants with more than a thousand 'friends' with, apparently, no kind of social interaction among those involved".

However, several international studies suggest that it is exactly in the strong interpersonal and intimate relations that we see the most significant benefits in terms of prevention and promotion of health. The strong and consistent inverse association of social bonds and the general mortality rate was one of the first effects identified among the benefits of a good social network on health ${ }^{19}$. 
In this sense, educational activities that foster greater interaction and personal relationship among the members of the group can be important actions to be considered for future experiences in FM online groups.

It is also worth mentioning that among the initiatives of greater interest for the patients are conferences with healthcare professionals, something possible to be explored with more emphasis on future research and education efforts.

As for the other most frequent suggestions to improve these groups (like the support of more healthcare professionals, need of psychological and legal support, regional discussion forums, list of medical experts on the subject and more technical videos on the subject), these can be an example for future actions to be articulated by the medical society and of health and associations of healthcare professionals and patients. The subjects of greater interest and the working methods highlighted in this article can also be taken into account for future online groups or as food for thought in existing communities in search of improvements. The research found out that Facebook is a resource often used by patients with FM, and that such users usually see a great value in the possibility of exchanging experiences with other people with similar conditions. The investigated community showed to have social relevance and impact in people's lives, but it faces difficulties in the engagement among members.

\section{CONCLUSION}

In face of these findings, new online support strategies can be better explored in future programs for patients, working on different forms to create personal bond in FM online groups, providing more social support for these patients, with initiatives that generate individualized attention to members and activities in synergy with the desires of the members of these communities such as virtual conferences, support from more health professionals in these environments, need of psychological and legal support, regional discussion forums, list of medical experts on the subject and more technical videos about FM.

\section{REFERENCES}

1. Murray E, Burns J, See TS, Lai R, Nazareth I. Interactive Health Communication Applications for people with chronic disease. Cochrane Database Syst Rev. 2004;18(4):CD004274.

2. Andrade GR, Vaitsman J. Apoio social e redes: conectando solidariedade e saúde. Ciênc Saúde Coletiva. 2002;7(4):925-34.

3. Luciano JV, Sabes-Figuera R, Cardeńosa E, T Peńarrubia-María M, Fernández-Vergel R, García-Campayo J, et al. Cost-utility of a psychoeducational intervention in fibromyalgia patients compared with usual care: an economic evaluation alongside a 12-month randomized controlled trial. Clin J Pain. 2013;29(8):702-11.

4. Goossens ME, Rutten-van Mölken MP, Leidl RM, Bos SG, Vlaeyen JW, Teeken-Gruben NJ. Cognitive-educational treatment of fibromyalgia: a randomized clinical trial. II. Economic evaluation. J Rheumatol. 1996;23(7):1246-54.

5. Camerini L, Camerini AL, Schultz PJ. Do participation and personalization matter? A model-driven evaluation of an internet-based patient education intervention for fibromyalgia patients. Patient Educ Couns. 2013;92(2):229-34.

6. van Uden-Kraan CF, Drossaert CH, Taal E, Seydel ER, van de Laar MA. Patientinitiated online support groups: motives for initiation, extent of success and success factors. J Telemed Telecare. 2010;16(1):30-4.

7. Johnsen JA, Rosenvinge JH, Gammon D. Online group interaction and mental health Ananalysis of three online discussion forums. Scand J Psychol. 2002;43(5):445-9.

8. van Uden-Kraan CF, Drossaert CH, Taal E, Lebrun CE, Drossaers-Bakker KW, Smi WM, et al. Coping with somatic illnesses in online support groups: do the feared disadvantages actually occur? Comput Human Behav. 2008;24(2):309-24.

9. Frost JH, Massagli MP. Social uses of personal health information within patients like me: an online patient community: what can happen when patients have access to one another's data. J Med Internet Res. 2008;10(3):e15.

10. Amaral A, Natal G, Viana L. Netnografia como aporte metodológico da pesquisa em comunicação digital. Cad Esc Comunic. 2008;6(1):34-40.

11. Jacopetti A. Práticas sociais e de comunicaçáo de pacientes renais no Facebook da Fundação Pró-Rim. Rev Estud Comun. 2011;12(27):81-9.

12. Lorig KR, Mazonson PD, Holman HR. Evidence suggesting that health education for self-management in patients with chronic arthritis has sustained health benefits while reducing health care costs. Arthritis Rheum. 1993;36(4):439-46.

13. Lorig KR, Ritter PL, Laurent DD, Plant K. The internet-based arthritis self-management program: a one-year randomized trial for patients with arthritis or fibromyalgia. Arthritis Rheum. 2008;59(7):1009-17.

14. Moretti FA, Zucchi P. Characterization of support groups and patient associations for individuals with rheumatologic disease in Brazil. Rev Bras Reumatol. 2010;50(5):516-28.

15. Berber JS, Kupek E, Berber SC. Prevalência de depressão e sua relaçăo com a qualidade de vida em pacientes com síndrome da fibromialgia. Rev Bras Reumatol. 2005;45(2):47-54

16. Carvalheiro JR, Hélder P, Ricardo M. Público, Privado e representaçâo online: o caso do Facebook. Comunicação Digital - 10 anos de Investigação, Coimbra: Minerva Coimbra Ediçôes; 2013.

17. Kaufman D. A força dos "laços fracos" de Mark Granovetter no ambiente do ciberespaço. Galaxia. 2012;23:207-18.

18. Bauman Z. Amor líquido: sobre a fragilidade dos laços humanos. Zahar; 2004.

19. Chor D, Griep RH, Lopes CS, Faerstein E. [Social network and social support measures from the Pró-Saúde study: pre-tests and pilot study]. Cad Saude Publica. 2001;17(4):887-96. Portuguese. 